\title{
Analisa Faktor Inisiasi Menyusui Dini, Dukungan Suami Dan Promosi Susu Formula Terhadap Kegagalan Pemberian Asi Eksklusif (Studi Penelitian di Puskesmas Turi Kabupaten Lamongan)
}

\author{
Asyaul Wasiah \\ Dosen Program Studi Diploma III Kebidanan Universitas Islam Lamongan \\ Email : arsyilahasna5@gmail.com
}

\begin{abstract}
ABSTRAK
Berbagai studi menunjukkan cakupan ASI eksklusif di Indonesia masih sangat rendah. ASI eksklusif sangat penting bagi kelangsungan hidup bayi karena mengandung growth factor dan zat antibodi. Apabila ASI tidak diberikan secara eksklusif, proses pematangan sistem imun akan terganggu dan menyebabkan bayi mudah terserang infeksi. Tujuan penelitian ini adalah mengetahui faktor yang paling utama mempengaruhi kegagalan pemberian ASI Eksklusif di Puskesmas turi, Kabupaten Lamongan.

Penelitian ini analitik deskirptif dengan desain cross sectional. Sampel $132 \mathrm{ibu}$ dengan bayi usia 6-12 bulan menggunakan teknik Simple Random Sampling, instrumen kuesioner, analisis data dengan uji Regresi Logistik.

Sebagian besar ibu tidak melakukan inisiasi menyusui dini yaitu $78(59,1 \%)$, mendapat dukungan suami cukup 80 responden $(60,6 \%)$ dan tertarik promosi susu formula sebanyak 74 responden $(56,1 \%)$. Untuk uji parsial Inisiasi menyusui dini mempunyai nilai Sig 0,003, Dukungan suami nilai Sig 0,004 dan promosi susu formula nilai Sig 0,001. Hasil analisis variabel paling dominan terhadap kegagalan pemberian ASI Eksklusif adalah dukungan suami dengan nilai OR 1.868 .

Diharapkan agar meningkatkan penyuluhan dan informasi tentang Inisiasi Menyusu Dini serta ASI Ekslusif kepada ibu hamil dan ibu memiliki bayi. Serta lebih selektif dalam menerima segala bentuk upaya promosi susu formula dari berbagai media promosi.
\end{abstract}

\section{Kata Kunci : ASI Eksklusif, ibu menyusui}

\section{ABSTRACT}

Various studies show that the coverage of exclusive breastfeeding in Indonesia is still very low. There are various factors that influence the failure of exclusive breastfeeding. Exclusive breastfeeding is very important for the survival of the baby because it contains growth factors and antibody substances. If breast milk is not given exclusively, the immune system's maturation process will be disrupted and cause the baby to get infected easily. The purpose of this study was to find out the most dominant factors affecting the failure of exclusive breastfeeding at the turi health center, Lamongan Regency

His research is quantitative with cross sectional design. A sample of 132 mothers who have babies aged 6-12 months used the Simple Randem Sampling technique, using primary data with a questionnaire instrument, data analysis with the Logistic Regression test. The place and time of research at the Turi Health Center, Lamongan Regency.

Based on research, most of the mothers did not initiate early breastfeeding, namely 78 (59.1\%), mothers received sufficient husband support, namely 80 respondents (60.6\%) and most mothers were interested in promoting formula milk as many as 74 respondents (56.1\% ) For partial test Early breastfeeding initiation has a Sig Wald value of $0.003<0.05$, Husband's support for the Sig Wald value of $0.004<0.05$ and milk promotion formula for the Sig Wald value of $0.001<0.05$. The results of the analysis using the most dominant Logistic 
Regression test on the failure of Exclusive ASI were husband's support with an OR value of 1.868 .

It is hoped that we will improve counseling and provide information about Early Breastfeeding Initiations and the benefits of exclusive breastfeeding early to pregnant women and mothers who have babies. As well as being more selective in receiving information on formula milk and not necessarily accepting all forms of promotion of formula milk from various promotional media.

\section{Keywords: Exclusive breastfeeding, breastfeeding mother}

\section{PENDAHULUAN}

World Health Organisation (WHO) menganjurkan agar pemberian ASI dilakukan secara eksklusif sejak bayi lahir hingga bayi berusia enam bulan. Anjuran tersebut telah diikuti oleh berbagai negara di dunia, salah satunya Indonesia. Walaupun ASI eksklusif telah dianjurkan oleh pemerintah, kegagalan ASI eksklusif sangat umum terjadi di Indonesia.

Berdasarkan data dari Kementerian Kesehatan Republik Indonesia tahun 2017 persentase bayi mendapat ASI Eksklusif sampai usia 6 bulan sebesar 34,92\%. Mengacu pada target renstra tahun 2016 sebesar $42 \%$, maka cakupan pemberian ASI eksklusif pada bayi usia kurang dari enam bulan untuk Propinsi Jawa Timur masih kurang dari target. Di Kabupaten Lamongan, pada tahun 2017 jumlah bayi yang ada sebesar 18.542 sementara yang diberi ASI eksklusif sebesar 13.600 bayi (73,3\%). Cakupan terendah adalah Puskesmas Turi dari jumlah 446 bayi usia 0-6 bulan hanya 94 bayi mendapat ASI Eksklusif dengan cakupan sebesar $22,0 \%$.

ASI eksklusif merupakan suatu perilaku, menurut teori perilaku Lawrence Green, terdapat tiga faktor yang dapat membentuk perilaku yaitu faktor predisposisi, faktor pemungkin, dan faktor pendorong. Faktor predisposisi terwujud dalam faktor sosio-demografi, seperti status pekerjaan dan pendapatan. Faktor pemungkin terwujud dalam fasilitas yang dapat memungkinkan terjadinya perubahan perilaku. Fasilitas yang dimaksud seperti tempat bersalin (rawat gabung) dan ketersediaan ruang ASI di tempat kerja. Sementara itu, faktor pendorong terwujud dalam pemikiran orang lain yang dianggap berpengaruh, misalnya petugas kesehatan yang memberikan informasi-informasi terkait Inisiasi Menyusu Dini (IMD), ASI eksklusif dan dukungan suami (Wendiranti, 2017).
Inisiasi Menyusu Dini dalam 30 menit setelah melahirkan memiliki efek yang mendalam terhadap pendirian dan lama menyusui ibu. Penelitian Syafiq 2012 menerangkan bahwa ibu yang menyusui dalam satu jam pertama mempunyai peluang 2 sampai 8 kali lebih besar untuk memberikan ASI Eksklusif sampai empat bulan jika dibandingkan yang tidak. Namun kenyataan yang ada jarang di tempat persalinan melakukan hal tersebut yang ada justru menjadi sarana bagi produsen susu formula untuk memasarkan produk mereka. Dibutuhkan dukungan keluarga terutama suami dalam keberhasilan ASI eksklusif.

Tenaga Kesehatan memegang peranan penting dalam mendukung keberhasilan ASI Ekslusif maka perlu dilakukan upaya antara lain penyuluhan pada ibu saat hamil tentang persiapan Inisiasi Menyusui dini, ASI Eksklusif dengan melibatkan suami ibu sehingga pengetahuan mereka bertambah dan tidak terjadi kegagalan pemberian ASI Ekslusif.

Informasi tentang pentingnya pemberian ASI Eksklusif secara optimal sedini mungkin akan mempengaruhi perilaku ibu juga dalam memberikan ASInya kelak saat masa menyusui, selain pengalaman melahirkan dan dukungan orang sekitar terutama suami.

\section{HIPOTESIS}

Hipotesis dalam penelitian ini adalah

1) Ada Pengaruh Inisiasi Menyusui Dini terhadap Kegagalan Pemberian ASI Eksklusif di Puskesmas Turi, Lamongan

2) Ada Pengaruh Dukungan Suami terhadap Kegagalan Pemberian ASI Eksklusif di Puskesmas Turi, Lamongan

3) Ada Pengaruh Promosi Susu Formula terhadap Kegagalan Pemberian ASI Eksklusif di Puskesmas Turi, Lamongan 
4) Ada Pengaruh faktor yang dominan terhadap Kegagalan Pemberian ASI Eksklusif di Puskesmas Turi, Lamongan

\section{METODE PENELITIAN}

Desain penelitian ini deskriptif analitik dengan menggunakan rancangan studi cross sectional ( study potong lintang) yaitu peneliti mempelajari hubungan antar variabel bebas dan variabel terikat dengan melakukan pengukuran sesaat, tidak semua objek penelitian harus diperiksa pada hari atau saat yang sama tetapi baik variabel efek dinilai hanya satu kali saja (Siregar, 2012).

Tempat dan waktu penelitian ini dilakukan pada tanggal 14 s/d 31 Desember 2018 di Puskesmas Turi, Kabupaten Lamongan. Variabel bebas (Inisiasi Menyusui Dini, dukungan suami dan promosi susu formula), variabel terikat (kegagalan ASI Eksklusif). Populasi ibu yang mempunyai bayi 6-12 bulan berjumlah 196 orang.

Jumlah sampel adalah 132 responden dengan tehnik Simple random sampling . Instrumen pada penelitian ini menggunakan lembar kuesioner. Analisa data dengan Regresi Logistik dan telah lolos uji etik.

\section{HASIL DAN PENELITIAN}

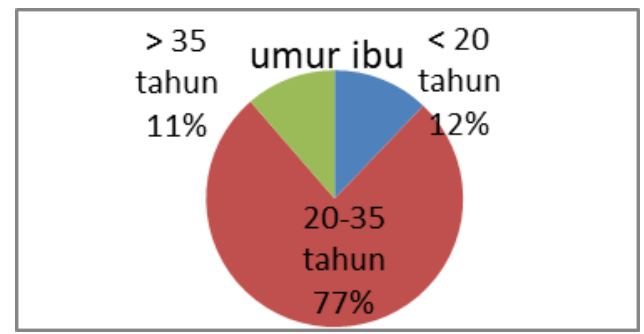

Gambar 4.1 Distribusi frekuensi responden berdasarkan umur ibu

Berdasarkan gambar 4.1 menunjukkan bahwa dari 132 responden hampir seluruhnya usia ibu post partum antara 20 - 35 tahun yaitu 101 responden $(77 \%)$.

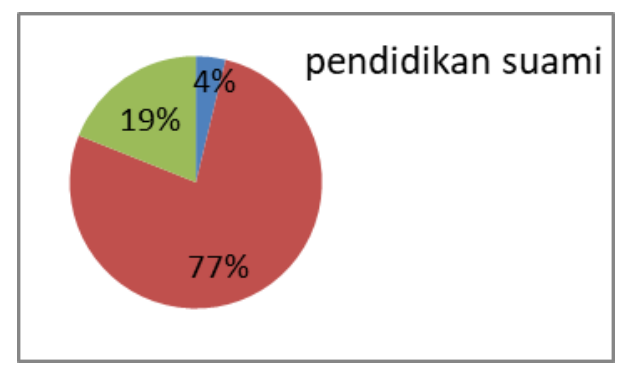

Gambar 4.2 Distribusi frekuensi berdasarkan pendidikan suami

Berdasarkan gambar 4.2

Menunjukkan bahwa dari 132 responden sebagian besar tingkat pendidikan terakhir suami SMA yaitu 102 responden (77\%).

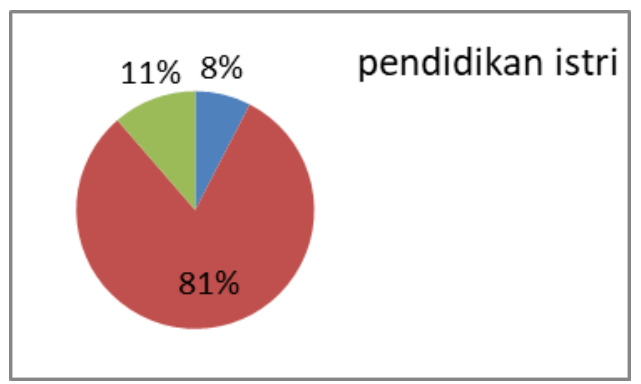

Gambar 4.3 Distribusi frekuensi berdasarkan pendidikan istri

Berdasarkan gambar 4.3 Menunjukkan bahwa dari 132 responden sebagian besar tingkat pendidikan terakhir istri SMA yaitu 107 responden (81\%).

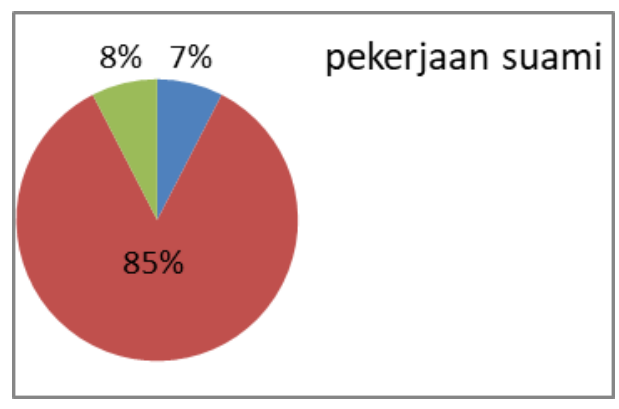

Gambar 4.4 Distribusi frekuensi responden berdasarkan Pekerjaan suami
Berdasarkan
gambar
4.4

Menunjukkan bahwa dari 132 responden hampir seluruhnya pekerjaan suami adalah swasta yaitu 112 responden (85\%).

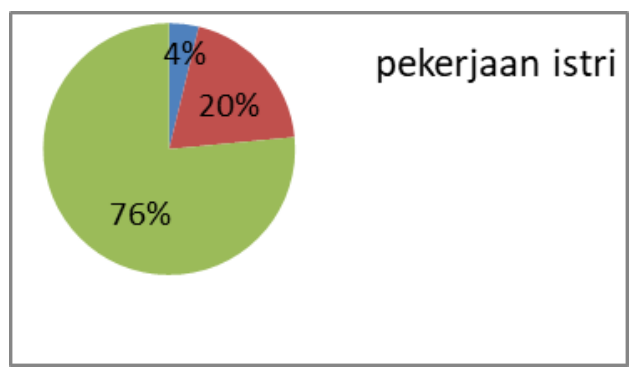

Gambar 4.5 Distribusi frekuensi responden berdasarkan Pekerjaan istri

Berdasarkan gambar 4.5 Menunjukkan bahwa dari 132 responden hampir seluruhnya pekerjaan ibu sebagai ibu rumah tangga yaitu 101 responden $(76,5 \%)$. 
Tabel 4.1 Distribusi frekuensi Riwayat Inisiasi Menyusui Dini

\begin{tabular}{cccc}
\hline No & $\begin{array}{c}\text { Inisiasi } \\
\text { Menyusui Dini }\end{array}$ & $\begin{array}{c}\text { Frek } \\
(\mathrm{n})\end{array}$ & $(\%)$ \\
\hline 1 & Tidak IMD & 78 & 59,1 \\
2 & IMD & 54 & 40,9 \\
& Total & 132 & 100 \\
\hline
\end{tabular}

Sumber : Data Primer Hasil Penelitian 2018

Berdasarkan Tabel 4.1 Menunjukkan bahwa dari 132 responden sebagian besar ibu tidak melakukan inisiasi menyusui dini yaitu $78(59,1 \%)$.

Tabel 4.2 Distribusi frekuensi Dukungan Suami

\begin{tabular}{cccc}
\hline No & $\begin{array}{c}\text { Dukungan } \\
\text { suami }\end{array}$ & $\begin{array}{c}\text { Frekuensi } \\
(\mathrm{n})\end{array}$ & $(\%)$ \\
\hline 1 & Kurang & 5 & 3,8 \\
2 & Cukup & 80 & 60,6 \\
3 & Baik & 47 & 35,6 \\
& Total & 132 & 100 \\
\hline
\end{tabular}

Sumber : Data Primer Hasil Penelitian 2018

Berdasarkan Tabel 4.2 Menunjukkan bahwa dari 132 responden sebagian besar ibu mendapat dukungan suami cukup yaitu 80 responden $(60,6 \%)$.

Tabel 4.3 Distribusi frekuensi promosi susu formula

\begin{tabular}{cccc}
\hline No & $\begin{array}{c}\text { Promosi } \\
\text { susu } \\
\text { formula }\end{array}$ & $\begin{array}{c}\text { Frekuensi } \\
(\mathrm{n})\end{array}$ & $\begin{array}{c}\text { Prosentase } \\
(\%)\end{array}$ \\
\hline 1 & Tertarik & 74 & 56,1 \\
2 & Tidak & 58 & 43,9 \\
& tertarik & & \\
& Total & 132 & 100 \\
\hline
\end{tabular}

Sumber : Data Primer Hasil Penelitian 2018

Berdasarkan Tabel 4.3 Menunjukkan bahwa dari 132 responden sebagian besar ibu tertarik dengan promosi susu formula sebanyak 74 responden $(56,1 \%)$.

Tabel 4.4 Distribusi kegagalan ASI Eksklusif

\begin{tabular}{cccc}
\hline No & $\begin{array}{c}\text { Kegagalan } \\
\text { ASI } \\
\text { Eksklusif }\end{array}$ & $\begin{array}{c}\text { Frek } \\
(\mathrm{n})\end{array}$ & $\begin{array}{c}\text { Prosentase } \\
(\%)\end{array}$ \\
\hline 1 & Gagal & 85 & 64,4 \\
2 & ASI & 47 & 35,6 \\
& Eksklusif & & \\
& Total & 132 & 100 \\
\hline
\end{tabular}

Sumber : Data Primer Hasil Penelitian 2018

Berdasarkan Tabel 4.4 Menunjukkan bahwa dari 132 responden sebagian besar ibu gagal ASI Eksklusif sebanyak 85 responden $(64,4 \%)$.
Tabel 4.15 Tabulasi Silang Inisiasi Menyusui Dini dengan Kegagalan ASI Eksklusif

\begin{tabular}{|c|c|c|c|c|c|}
\hline & & & $\begin{array}{r}\text { Kegaga } \\
\text { Eksl }\end{array}$ & $\begin{array}{l}\text { n ASI } \\
\text { sif }\end{array}$ & Total \\
\hline & & & Gagal & $\begin{array}{c}\text { ASI } \\
\text { Ekskl } \\
\text { usif }\end{array}$ & \\
\hline$\overline{\mathrm{IMD}}$ & Tidak & Angka & 74 & 4 & 78 \\
\hline & & $\begin{array}{l}\text { Jumlah } \\
(\%)\end{array}$ & $94,9 \%$ & $5,1 \%$ & $100 \%$ \\
\hline & $\overline{\mathrm{IMD}}$ & Angka & 11 & 43 & 54 \\
\hline & & $\begin{array}{l}\text { Jumlah } \\
(\%)\end{array}$ & $20,4 \%$ & $79,6 \%$ & $100 \%$ \\
\hline Total & & Angka & 85 & 47 & 110 \\
\hline & & $\begin{array}{l}\text { Jumlah } \\
\%\end{array}$ & $64,4 \%$ & $35,6 \%$ & $\begin{array}{r}100.0 \\
\%\end{array}$ \\
\hline & & $=77,246$ & value $=0$ & & \\
\hline
\end{tabular}

Berdasarkan tabel 4.15 menunjukkan bahwa dari 132 responden hampir seluruhnya ibu yang tidak melakukan Inisiasi Menyusui Dini mengalami kegagalan dalam pemberian ASI Eksklusif yaitu 74 (94,9\%).

Tabel 4.16 Tabulasi Silang Dukungan Suami dengan Kegagalan ASI Eksklusif

\begin{tabular}{|c|c|c|c|c|c|}
\hline & & & $\begin{array}{r}\text { Kegage } \\
\text { Eks }\end{array}$ & $\begin{array}{l}\text { n ASI } \\
\text { isif }\end{array}$ & Total \\
\hline & & & Gagal & $\begin{array}{c}\text { ASI } \\
\text { Ekskl } \\
\text { usif }\end{array}$ & \\
\hline \multirow{6}{*}{$\begin{array}{l}\text { Duku } \\
\text { ngan } \\
\text { suami }\end{array}$} & \multirow{2}{*}{$\begin{array}{l}\text { Kura } \\
\text { ng }\end{array}$} & Angka & 5 & 0 & 5 \\
\hline & & $\begin{array}{l}\text { Jumlah } \\
(\%)\end{array}$ & $100 \%$ & $0 \%$ & $100 \%$ \\
\hline & \multirow[t]{2}{*}{ Cukup } & Angka & 75 & 5 & 80 \\
\hline & & $\begin{array}{l}\text { Jumlah } \\
(\%)\end{array}$ & $93,8 \%$ & $6,3 \%$ & $100 \%$ \\
\hline & \multirow[t]{2}{*}{ Baik } & Angka & 5 & 42 & 47 \\
\hline & & $\begin{array}{l}\text { Jumlah } \\
(\%)\end{array}$ & $10,6 \%$ & $89,4 \%$ & $100 \%$ \\
\hline \multirow[t]{3}{*}{ Total } & & Angka & 85 & 47 & 132 \\
\hline & & $\begin{array}{l}\text { Jumlah } \\
\%\end{array}$ & $64,4 \%$ & $35,6 \%$ & $\begin{array}{r}100.0 \\
\%\end{array}$ \\
\hline & & $2^{2}=92,068$ & \multicolumn{2}{|c|}{$p$ value $=0,000$} & \\
\hline
\end{tabular}

Berdasarkan tabel 4.16 menunjukkan bahwa dari 132 responden sebagian besar responden yang mendapat dukungan suami cukup gagal dalam memberikan ASI Eksklusif yaitu 75 responden $(93,8 \%)$.

Tabel 4.17 Tabulasi Silang promosi susu formula dengan Kegagalan ASI Eksklusif

\begin{tabular}{|c|c|c|c|c|c|}
\hline & & & $\begin{array}{r}\text { Kega } \\
\text { A } \\
\text { Eksk }\end{array}$ & $\begin{array}{l}\text { lan } \\
\text { sif }\end{array}$ & Total \\
\hline & & & Gagal & $\begin{array}{l}\text { ASI } \\
\text { Eks } \\
\text { klus } \\
\text { if }\end{array}$ & \\
\hline \multirow{4}{*}{$\begin{array}{l}\text { Promo } \\
\text { si susu } \\
\text { formu } \\
\text { la }\end{array}$} & \multirow{2}{*}{$\begin{array}{l}\text { Tert } \\
\text { arik }\end{array}$} & Angka & 69 & 5 & 74 \\
\hline & & $\begin{array}{l}\text { Jumla } \\
\text { h (\%) }\end{array}$ & $\begin{array}{r}93,2 \\
\%\end{array}$ & $\begin{array}{r}6,8 \\
\%\end{array}$ & $100 \%$ \\
\hline & \multirow{2}{*}{$\begin{array}{l}\text { Tid } \\
\text { ak } \\
\text { terta } \\
\text { rik }\end{array}$} & Angka & 16 & 42 & 58 \\
\hline & & $\begin{array}{l}\text { Jumla } \\
\mathrm{h}(\%)\end{array}$ & $\begin{array}{r}27,6 \\
\%\end{array}$ & $\begin{array}{r}72,4 \\
\%\end{array}$ & $100 \%$ \\
\hline \multirow[t]{3}{*}{ Total } & & Angka & 85 & 47 & 132 \\
\hline & & $\begin{array}{l}\text { Jumla } \\
\text { h \% }\end{array}$ & $\begin{array}{r}64,4 \\
\%\end{array}$ & $\begin{array}{r}35,6 \\
\%\end{array}$ & $100.0 \%$ \\
\hline & \multicolumn{2}{|c|}{$X^{2}=61,134$} & value $=$ & 000 & \\
\hline
\end{tabular}


Berdasarkan tabel 4.17 menunjukkan bahwa dari 132 responden sebagian besar responden yang tertarik dengan promosi susu formula gagal dalam memberikan ASI Eksklusif yaitu 69 responden (93,2\%).

Hasil Analisis Regresi Logistik uji parsial menunjukkan nilai sebagai berikut : Variabel Inisiasi menyusui dini didapatkan nilai Sig Wald $0,003<0,05$ artinya Inisiasi menyusui dini memberikan pengaruh yang cukup besar terhadap kegagalan pemberian ASI eksklusif. Variabel Dukungan suami dengan nilai Sig Wald 0,004 $<0,05$ dimana dukungan suami juga memberikan pengaruh yang besar terhadap kegagalan pemberian ASI eksklusif. Variabel promosi susu formula dengan nilai Sig Wald $0,001<0,05$ artinya promosi susu formula juga memberikan andil yang besar terhadap kegagalan pemberian ASI eksklusif.

Besarnya pengaruh ditunjukkan dengan nilai EXP (B) atau disebut juga $O D D S$ RATIO (OR). Variabel Inisiasi Menyusui Dini dengan OR 1.271 maka ibu yang tidak Inisiasi Menyusui Dini, lebih beresiko mengalami kegagalan pemberian ASI eksklusif sebanyak 1.271 kali lipat. Nilai $\mathrm{B}=$ Logaritma Natural dari $1.271=$,367. Oleh karena nilai B bernilai positif, maka ibu yang tidak inisiasi menyusi dini mempunyai hubungan positif dengan kegagalan pemberian ASI eksklusif.

Variabel dukungan suami dengan OR 1.868 maka ibu yang kurang mendapat dukungan suami, lebih beresiko mengalami kegagalan pemberian ASI eksklusif sebanyak 1.868 kali lipat. Nilai $\mathrm{B}=$ Logaritma Natural dari $1.868=, 625$. Oleh karena nilai B bernilai positif, maka kurangnya dukungan suami mempunyai hubungan positif dengan kegagalan pemberian ASI eksklusif. Variabel promosi susu formula dengan OR 1,071 maka ibu yang tertarik dengan promosi susu formula beresiko mengalami kegagalan pemberian ASI eksklusif sebanyak 1,071 kali lipat. Nilai B $=, 169$. Oleh karena nilai B bernilai positif, maka ketertarikan dengan promosi susu formula mempunyai hubungan positif dengan kegagalan pemberian ASI eksklusif. Berdasarkan nilai EXP (B) atau $O D D S$ RATIO (OR) maka variabel dukungan suami sangat mempengaruhi kegagalan pemberian ASI Eksklusif.

\section{PEMBAHASAN}

1. Pengaruh Inisiasi Menyusui Dini terhadap Kegagalan Pemberian ASI Eksklusif.

Berdasarkan hasil Analisis uji Regresi logistik diperoleh $p$ value $0,003<\alpha=0,05$. Hasil penelitian diperoleh sebanyak 85 responden $(64,4 \%)$ gagal dalam memberikan ASI Eksklusif sebanyak 11 responden (20,4\%) berhasil melakukan IMD, dan 74 responden $(94,9 \%)$ tidak melakukan IMD,. Adapun dari 47 responden (32,8\%) responden yang berhasil dalam memberikan ASI Eksklusif, 43 responden $(79,6 \%)$ berhasil IMD dan 4 responden $(5,1 \%)$ tidak melakukan IMD.

Hasil penelitian yang dilakukan oleh Nurlaili (2014) yang menyatakan bahwa 45 responden $(67,3 \%)$ responden yang gagal dalam memberikan ASI Eksklusif, 5 responden $(20 \%)$ berhasil melakukan IMD, 40 responden $(95,2 \%)$ tidak melakukan IMD,. Adapun dari 22 responden $(32,8 \%)$ responden yang berhasil dalam memberikan ASI Eksklusif, 20 responden $(80 \%)$ berhasil IMD dan 2 responden $(4,8 \%)$ tidak melakukan IMD.

Menurut Handayani, 2016 Faktor Penyebab Kegagalan ASI Eksklusif disebabkan Antara lain dari spikologis ibu itu sendiri, kurangnya pengetahuan ibu tentang ASI eksklusif membuat ibu minder dan takut memberikan ASI, padahal sebenarnya produksi ASInya cukup untuk kebutuhan bayinya. Sehingga dibutuhkan motivasi yang besar agar ibu dapat memberikan ASI secara optimal

Faktor lain yang dapat mengurangi produksi ASI adalah tidak melakukan inisiasi menyusui dini, terlalu dini memberikan minuman prelaktal (bayi diberi minum sebelum ASI keluar), apalagi memberikannya dengan botol/dot, jadwal pemberian ASI, dan posisi menyusui yang salah.

Menurut Roesli, 2013 pada ibu dengan proses persalinan secara normal hendaknya bayi langsung dilakukan IMD. IMD disebut early initation atau permulaan menyusu dini, yaitu bayi mulai menyusui sendiri segera setelah lahir. Keberhasilan praktik IMD, dapat membantu agar proses pemberian ASI eksklusif berhasil, sebaliknya jika IMD gagal, akan menjadi penyebab pula terhadap gagalnya pemberian ASI Eksklusif .

Inisiasi menyusui dini ini merupakan salah satu titik awal yang sangat penting untuk menentukan keberhasilan menyusui karena dengan sedini mungkin bayi menyusu 
maka produksi ASI juga semakin meningkat dan kebutuhan gizi bayi tercukupi sehingga kemungkinan terjadinya kegagalan pemberian ASI eksklusif juga semakin rendah bahkan tidak ada.

\section{Pengaruh Dukungan suami terhadap Kegagalan Pemberian ASI Eksklusif.}

Berdasarkan hasil Analisis data diperoleh $p$ value $0,0004<\alpha=0,05$. Hasil penelitian yang dilakukan Di Puskesmas Turi diperoleh hasil dari 85 responden $(64,4 \%)$ responden yang gagal dalam memberikan ASI Eksklusif, 5 responden (100\%) kurang mendapat dukungan suami, 75 responden (93,8\%) cukup mendapat dukungan suami,. 5 responden $(10,6 \%)$ mendapat dukungan suami baik. Adapun dari 47 responden $(35,6 \%)$ responden yang berhasil dalam memberikan ASI Eksklusif, 0 responden kurang mendapat dukungan suami, 5 responden $(6,3 \%)$ cukup mendapat dukungan suami,. 42 responden $(89,4 \%)$ mendapat dukungan suami baik.

Hasil penelitian ini didukung oleh beberapa hasil penelitian terdahulu seperti penelitian yang dilakukan Suharti (Mei, 2018) menunjukkan ada hubungan yang signifikan antara dukungan suami dengan kegagalan pemberian ASI Eksklusif pada bayi di Puskesmas Ranotana Weru, dari 70 responden dengan dukungan suami baik ada 29 responden yang tidak memberikan ASInya secara eksklusif, 41 responden memberikan ASI Eksklusif. Dan sebanyak 33 responden dengan dukungan suami kurang, 27 responden tidak memberikan ASI Eksklusif dan memberikan ASI eksklusif sebanyak 6 orang,

Dukungan dari suami akan berpeluang memberikan ASI eksklusif sebesar 3 kali dibandingkan ibu yang tidak mendapatkan dukungan suami, Berdasarkan penelitian dari Evareny, 2010 juga memperlihatkan hubungan yang signifikan antara dukungan keluarga, peran ayah dengan perilaku pemberian ASI eksklusif.

Peran ayah yang mendukung akan memberikan dampak 25 kali lipat untuk ibu memberikan ASI Eksklusif dibandingkna ayah yang tidak mendukung. Pemberian ASI eksklusif tidak hanya mengandalkan pengetahuan dan sikap positif. Ketersediaan fasilitas dan waktu untuk memberikan ASI pada bayi menjadi hal lain yang perlu dipertimbangkan. Besarnya campur tangan keluarga dalam perawatan bayi juga mempengaruhi ibu dalam praktik pemberian ASI eksklusif ini.

Hal ini menunjukkan bahwa ayah memainkan peran penting dalam sukses tidaknya menyusui dan meningkatkan angka menyusui. Data pengamatan menunjukkan bahwa ayah memiliki peran penting dalam keputusan ibu tentang cara memberi makan bayi dan ibu yang memilih untuk memberikan susu botol atau menyusui untuk waktu yang lebih singkat ketika ayah tidak mendukung.

Keluarga, selain bisa menjadi faktor pendukung sekaligus justru bisa menjadi faktor penghambat. Keinginan ibu untuk memberikan ASI eksklusif sebaiknya sudah didiskusikan dengan keluarga terutama orang-orang yang akan tinggal bersama ibu saat bayi itu lahir misal suami, ibu, ibu mertua jauh sebelum si bayi lahir atau minimal saat fase kehamilan. Tanamkan kepada keluarga pentingnya ASI, bagaimana memberikan ASI eksklusif serta dukungan apa yang mereka bisa berikan.

\section{Pengaruh Promosi Susu Formula Terhadap Kegagalan Pemberian ASI Eksklusif}

Berdasarkan hasil Analisis data diperoleh $p$ value $0,001<\alpha=0,05$. Hasil penelitian yang dilakukan Di Puskesmas Turi diperoleh hasil dari 85 responden $(64,4 \%)$ responden yang gagal dalam memberikan ASI Eksklusif, 69 responden $(93,2 \%)$ tertarik dengan promosi susu formula, 16 responden $(27,6 \%)$ tidak tertarik dengan promosi susu formula. Adapun dari 47 responden $(35,6 \%)$ responden yang berhasil dalam memberikan ASI Eksklusif, 5 responden (6,8\%) tertarik dengan promosi susu formula, 42 responden $(72,4 \%)$ tidak tertarik dengan promosi susu formula.

Menurut penelitian dari Fikri Ulil Albab 2013 keluarga yang terpapar promosi susu formula cenderung mengalami ketidak berfungsian pengambilan keputusan keluarga dalam pemberian ASI eksklusif yaitu sebesar 78,9\% dibanding dengan keluarga yang tidak terpapar promosi susu formula hanya sebesar $57,1 \%$.

Promosi susu formula merupakan suatu penyebarluasan informasi produk susu formula untuk mempengaruhi dan mengingatkan pasar sasaran atau keluarga agar bersedia menerima, membeli dan loyal pada produk yang ditawarkan. Berdasarkan 
hasil penelitian, dari Mifbakhuddin (2015) menunjukkan bahwa lebih dari 50\% atau sebanyak 19 responden $(57,6 \%)$ terpapar promosi susu formula, sedangkan sebanyak 14 responden $(42,4 \%)$ tidak terpapar promosi susu formula. Hal ini terjadi karena promosi susu formula disebarluaskan melalui berbagai media komunikasi.

Perilaku konsumtif terutama penggunaan susu formula tidak hanya terjadi pada masyarakat perkotaan bahkan masyarakat desa juga sudah mulai mewabah. Sarana komunikasi dan transportasi yang terus berkembang memudahkan distributor susu formula untuk mempromosikan produknya.

Tidak hanya melalui televisi, radio dan surat kabar melainkan juga langsung datang ke tempat-tempat toko atau swalayan yang menjual produk susu formula, dimana mereka bisa komunikasi langsung dengan konsumen. Sehingga paradigma pergeseran dari pemberian Asi Eksklusif ke pemberian susu formula terlihat semakin nyata.

Rangsangan promosi susu formula melalui berbagai media promosi dapat membentuk suatu sikap dan perilaku untuk melakukan pembelian. Jika persepsi terhadap produk berkualitas semakin kuat, maka akan menguatkan sikap yang akan mempengaruhi niat untuk membeli produk tersebut dan pada akhirnya merubah perilaku positif kearah negatif dengan tidak akan memberikan ASI eksklusif kepada bayinya.

Media promosi penjualan dan pemasaran langsung memiliki tingkat keterpaparan yang tinggi hal itu membuktikan bahwa masyarakat tertarik dengan adanya promosi penjualan produk melalui pemberian potongan harga, kupon, diskon dan sampel produk yang mudah ditemui di kios, toko atau supermarket diberbagai tempat Keterpaparan responden terhadap promosi susu formula melalui hubungan masyarakat lebih mengkhawatirkan, karena produsen langsung memasarkan produknya ke ibu-ibu.

\section{Faktor yang dominan mempengaruhi Kegagalan Pemberian ASI Eksklusif}

Variabel yang paling dominan terhadap kegagalan pemberian ASI Eksklusif di Puskesmas Turi Lamongan adalah dukungan suami dengan nilai $O R$ yaitu 1,868 , artinya ibu yang kurang mendapat dukungan suami lebih beresiko mengalami kegagalan pemberian ASI eksklusif sebanyak 1.868 kali lipat
Hasil penelitian yang dilakukan Di Puskesmas Turi didapatkan 85 responden $(64,4 \%)$ yang gagal dalam memberikan ASI Eksklusif, 75 responden (93,8\%) cukup mendapat dukungan suami. Sedangkan dari 47 responden $(35,6 \%)$ responden yang berhasil dalam memberikan ASI Eksklusif, 42 responden $(89,4 \%)$ mendapat dukungan suami baik.

Dari 4 jenis dukungan suami yang paling banyak dijawab dengan jawaban benar oleh responden adalah dukungan emosional atau psikologis yang berupa suami menjaga perasaan ibu dengan menunjukkan sikap ramah, suami memberikan motivasi kepada ibu untuk menyusui bayinya, suami mengingatkan ibu waktu menyusui. Selain itu di Puskesmas Turi Lamongan sudah menerapkan pendampingan suami pada setiap ibu bersalin

Peran keluarga terutama suami juga menentukan keberhasilan pemberian ASI Eksklusif. Suami responden pada penelitian ini sebagian besar berpendidikan SMA, dimana seorang yang mempunyai pendidikan tinggi akan lebih mudah untuk menerima informasi dan pengetahuan. Berbeda dengan seorang yang hanya lulusan SD atau tidak sekolah.

Pekerjaan suami responden pada penelitian ini sebagian besar bekerja swasta. Keadaan ekonomi yang cukup atau lebih akan memudahkan seorang kepala keluarga untuk mencukupi kebutuhan keluarganya terutama kebutuhan primer seperti makanan. Dimana ibu yang memberikan ASI sangat membutuhkan asupan gizi atau makanan yang cukup dan bergizi.

Hanulan Septiani juga mengungkapkan dukungan keluarga berhubungan sangat erat terhadap pemberian ASI Eksklusif, di mana ibu yang mendapatkan dukungan dari keluarga berpeluang 7,6 kali untuk memberikan ASI eksklusif dibandingkan ibu yang tidak mendapat dukungan dari keluarga.

Dukungan emosional atau psikologis merupakan bentuk dukungan yang membuat ibu memiliki perasaan nyaman, yakin, diperdulikan. Menurut Friedman dukungan suami merupakan dukungan yang tiada duanya, karena memberikan efek yang positif bagi ibu menyusui. Suasana dan situasi yang kondusif akan melancarkan pemberian Asi Eksklusif, hal itu dapat dilakukan oleh suami dengan cara menemani ibu saat menyusui, membantu ibu untuk melengkapi kebutuhan saat menyusui dan memberikan pujian setiap ibu berhasil menyusui bayinya. 
Dari semua dukungan bagi ibu menyusui dukungan sang ayah adalah dukungan yang paling berati. Ayah dapat berperan aktif dalam keberhasilan pemberian ASI eksklusif dengan cara berikan dukungan secara emosional dan bantuan-bantuan yang praktis. Untuk membesarkan seorang bayi, masih banyak yang dibutuhkan selain menyusui seperti menyendawakan bayi, menggendong dan menenangkan bayi yang gelisah, mengganti popok, memandikan bayi, membawa bayi jalan-jalan di taman, memberikan ASI perah, dan memijat bayi. Kecuali menyusui semua tugas tadi dapat dikerjakan oleh ayah.

Breastfeeding father merupakan istilah yang diberikan pada ayah yang mendukung pemberian ASI Eksklusif. Pada dasarnya alasan fisiologis bukan menjadi kesimpulan bahwa ibu tidak dapat memberikan ASI asalkan ada kemauan dan niat maka setiap permasalahan dapat diatasi. Jadi, sebagian besar ibu dapat menyusui dengan baik. Hanya saja ketaatan mereka untuk menyusui ekslusif 4-6 bulan dan dilanjutkan hingga dua tahun yang mungkin tidak dapat dipenuhi secara menyeluruh. Itulah sebabnya dorongan ayah dan kerabat lain diperlukan untuk meningkatkan kepercayaan diri ibu akan kemampuan menyusui secara sempurna adalah dukungan suami.

\section{KESIMPULAN DAN SARAN \\ Kesimpulan}

Ada pengaruh Inisiasi Menyusui Dini, dukungan suami dan promosi susu formula terhadap kegagalan pemberian ASI eksklusif. Besarnya pengaruh untuk variabel Inisiasi Menyusui Dini nilai OR 1.271, variabel dukungan suami nilai OR 1.868, dan variabel promosi susu formula nilai OR 1,071.

\section{Saran}

Diharapkan agar kita meningkatkan penyuluhan dan memberikan informasi tentang Inisiasi Menyusu Dini dan manfaat pemberian ASI Ekslusif secara dini kepada ibu-ibu hamil dan ibu yang memiliki bayi. Serta lebih selektif dalam menerima informasi susu formula dan tidak serta-merta menerima segala bentuk upaya promosi susu formula dari berbagai media promosi.

\section{DAFTAR PUSTAKA}

Badriul, dkk. 2008. Journal of Maternal and Child Health, Qualitative Analysis on the Factors Affecting Exclusive Breastfeeding among Working

\author{
others at Community Health \\ Center, 1(2): 110-118
}

Fikawati S dan Syafiq A. 2012. Kajian Implementasi dan Kebijakan Air Susu Ibu Eksklusif dan Inisiasi Menyusui Dini di Indonesia. Makara Indonesia,14 (1): 17-24, Juni 2012

Fikri Ulil Albab, dkk. 2013. Hubungan Promosi Susu Formula dengan Pengambilan Keputusan Keluarga. Universitas Jember

Friedman MM., BowdenV., Jones E. 2013. Keperawatan Keluarga, Riset, Teori dan Praktik Ed. 5. Jakarta: EGC

Friedman, M. M., Bowden, V. R., dan Jones,E.G. 2010. Buku Ajar Keperawatan keluarga: Riset,Teori \& Praktik. Alih bahasa oleh Achir Yani S,et al., Jakarta: EGC

Gupta, A., Padhich, J. P., Suri, S. 2013. How Global Rates of Exclusive Breastfeeding For The First 6Months Be Enhanced. ICAN. Vol. 5(3): 133-140,

Hanulan Septiani, dkk. 2017. Jurnal Aisyah, Jurnal Ilmu Kesehatan, FaktorFaktor yang Berhubungan dengan Pemberian ASI Eksklusif Oleh Ibu Menyusui yang Bekerja Sebagai Tenaga Kesehatan. 159 - 174

Kementerian Kesehatan. 2014. Pusat Data dan Informasi 2014: Situasi dan Analisis ASI Eksklusif. Jakarta, Kementerian Kesehatan Republik Indonesia

Maria. 2013 Menyusui Cara Mudah, Praktis, dan Nyaman, Jakarta: Arcan

Maryunani Anik. 2015. Asuhan Ibu Nifas dan Asuhan Ibu Menyusui. Jakarta: In media

Maryunani Anik. 2013. Inisiasi Menyusui Dini, ASI Eksklusif dan Manajemen Laktasi. Jakarta : Trans Info Media

Notoatmojo S. 2015. Metodologi Penelitian Kesehatan. Jakarta : Rineka Cipta 
Prasetyono. 2012. Buku Pintar ASI Eksklusif. Yogyakarta : Diva Press

Purwanti Sri Hubertin. 2014. Konsep Penerapan ASI Eksklusif. Jakarta : EGC

Proverawati dan Rahmawati. 2010. Kapita Selekta ASI dan Menyusui. Yogyakarta : Nuha Media.

Roesli Utami. 2013. Panduan Konseling Menyusui. Jakarta : Pustaka Bunda.

Suharti JF, dkk. 2018. e-Journal Keperawatan (eKp), Hubungan dukungan keluarga dengan pemberian ASI Eksklusif, Volume 6 Nomor 1

Wendiranti Catra Ibriza, dkk. 2017. Journal of Nutrition College, Faktor Resiko Keggalan ASI Eksklusif. 23376236

Widuri Hesti. 2013. Manajemen Pemasaran. Jakarta : Social Agency Putera. 